\title{
ダラツムマブ治療中の患者検体測定後に不規則抗体スクリーニングの偽陽性反応が 多発した事例
}

\begin{tabular}{|c|c|c|c|c|c|}
\hline 真哉1) & 池本 & 純子'1) & 吉原＼cjkstart享子11)2) & 迁本 & 真年 \\
\hline 由紀 ${ }^{1)}$ & 杉山 & 寛貴 ${ }^{1)}$ & 小野本仁美 ${ }^{1)}$ & 村田 & 理息 \\
\hline & 日笠 & 聡1)2) & 吉原 & & \\
\hline
\end{tabular}

抗 CD38 モノクローナル抗体薬 (ダラッムマブ，イサッキシマブ) 投与患者検体を用いた不規則抗体スクリーニン グでは, 赤血球試薬表面上にも CD38 抗原が発現していることから沉反応性に偽陽性を呈する.

全自動輸血検查装置 IH-1000（BIO-RAD 社）を用いてダラッムマブ投与患者検体の不規則抗体スクリーニングと 直接抗グロブリン試験を実施した後, 測定当日の他検体の検查では偽陽性反応は出現しなかったが, 翌日の不規則抗 体スクリーニングにおいて複数の偽陽性反応が出現した，再現性を検証したところ，同様の反応が得られた.

原因としては, サンプルプローブを介したキャリーオーバーにより装置内の赤血球試薬に患者検体中のダラッムマ ブが混入したと考えられるが, 発生する条件等についてはさらなる検討が必要である.ダラッムマブ皮下注製剤では 静注製剂と異なり投与量が固定量であることから, 低体重患者における血中濃度上昇から本事象が起こりやすくなっ た可能性も考えられる. 他の全自動検查装置でも同様の事象が発生する可能性は否定できず, 抗 CD38 抗体薬治療中 の患者検体を全自動輸血検査装置で検査する場合には注意が必要である.

キーワード : 多発性骨髄腫，抗 CD 38 モノクローナル抗体薬，全自動輸血検査装置，偽陽性，キャリーオーバー

\section{はじめに}

抗 CD38 モノクローナル抗体薬(ダラツムマブ, イサ ツキシマブ) は, 多発性骨髄腫治療に扔けるキードラッ グである. 特にダラッムマブについては, 移植非適応 の初発多発性骨髄腫症例における推奨治療として日本 血液学会のガイドラインにおいて挙げられている $2 つ$ のレジメンのいずれにも含まれており ${ }^{1}$, 投与される機 会は非常に多い.

CD38 は形質細胞に特異的ではなく赤血球にも弱く発 現している ${ }^{2}$. そのため, 抗 CD38 抗体薬投与後症例の 検查では，不規則抗体スクリーニング (SC) や交差適 合試験の間接抗グロブリン試験(IAT)において沉反応 性の偽陽性を呈することが知られている。これに対し， DTT（DL-ジチオトレイトール）を用いて化学的に赤 血球表面上の CD38 を破壊することで，血漿(血清)中 の抗 CD38 抗体薬との反応を回避することができる ${ }^{3}$. 当院では抗 CD 38 抗体薬投与患者の情報を診療科と共有 し，投与前に不規則抗体の有無を確認し ${ }^{4)}$, 投与後の交 差適合試験時には全例，検查に用いる供血者赤血球の
DTT 処理を行なっている.

今回, ダラッムマブ治療中の症例に扔ける交差適合 試験実施時, 確認目的で SC を全自動輸血検查装置 (IH1000）で実施したところ，その翌日に偽陽性反応が多 発するという事例が発生した，本事象は今後も同様に 発生する可能性があり, 輸血部門への影響が大きいと 考えられるため報告する.

\section{ダラツムマブ治療症例の検査翌日に発生した偽陽性 反応}

ダラツムマブ治療中であった症例は 80 歳男性, 体重 は $37 \mathrm{~kg} . \quad$ IgA- $\lambda$ 型骨髄腫に対し DRd（ダラッムマブ+ レナリドミド+デキサメタゾン) 療法を開始した．ダ ラツムマブは皮下注製剤を用いられており，レジメン に則って day 1，8，15 に投与が行われた. day19 に直 接抗グロブリン試験（DAT）と SC の依頼があり $\mathrm{IH}-$ 1000 で検查を実施した. 同一プローブで次バッチに SC を行ったが特に問題なく, その後, 業務終了時のコン トロール測定までの ABO 血液型 24 件, SC24 件, DAT

1）兵庫医科大学病院輸血・細胞治療センター

2) 兵庫医科大学病院血液内科

3）兵庫医科大学先端医学研究所分子細胞治療部門

〔受付日：2021 年 8 月 6 日, 受理日 : 2021 年 9 月 22 日〕 


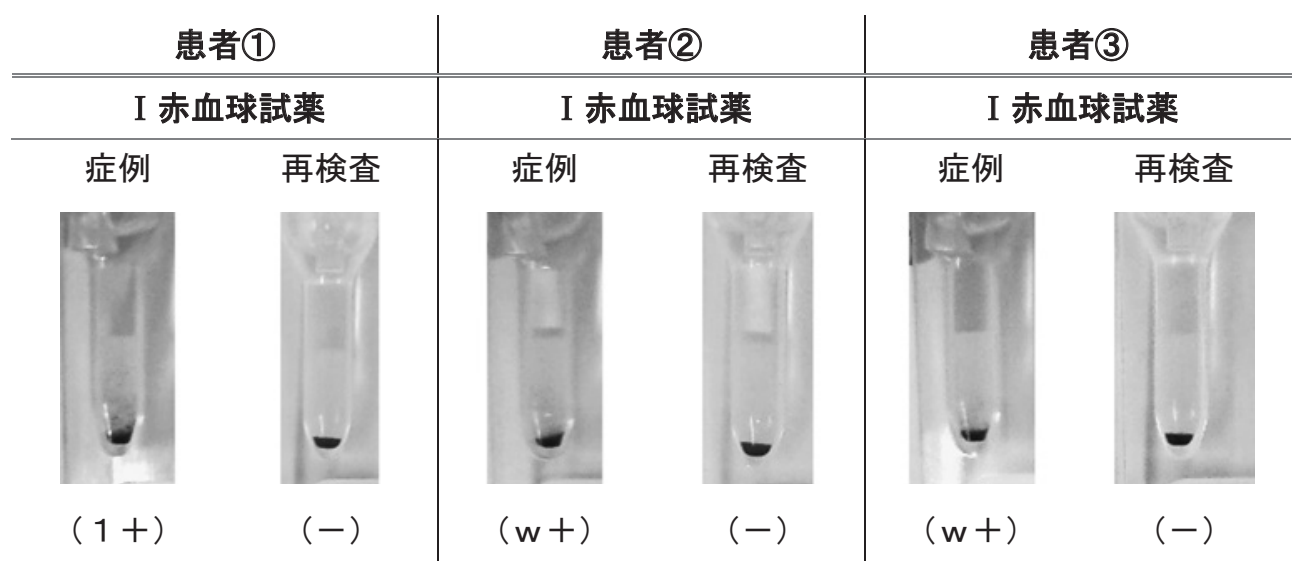

図 1 ダラッムマブが混入した赤血球試薬の使用により偽陽性を呈した患者 3 名の SC 3 検体とも，I赤血球試薬において偽陽性反応を認めた.

ID-DiaCell I-II-III (lot : 45188201)

マイクロタイピングシステム AHG4/ENZ2 カード (lot：50576412)

表 1

A ダラツムマブ治療中の患者検体測定前後の赤血球試薬における DAT

\begin{tabular}{lcccc}
\hline & $\mathrm{I}$ & $\mathrm{II}$ & $\mathrm{III}$ & $\mathrm{Di}^{\mathrm{a}}$ \\
\hline 測定前 (対照) & 0 & 0 & 0 & 0 \\
測定直後 & 0 & 0 & 0 & 0 \\
$24 \mathrm{H}$ & $1+$ & 0 & 0 & 0 \\
症例 & $1+$ & $\mathrm{w}+$ & \pm & 0 \\
\hline
\end{tabular}

ID-DiaCell I-II-III (lot : 45188201)

ID-DiaCell Di ${ }^{\mathrm{a}}$ (lot : 05984221)

マイクロタイピングシステム AHGカード (lot：50536413)

B 抗体混入が疑われる I 赤血球試薬の上清を用いた不規則抗体スクリーニング

\begin{tabular}{|c|c|c|c|c|c|}
\hline \multicolumn{4}{|c|}{ IAT } & \multicolumn{2}{|c|}{ ENZ } \\
\hline I & II & III & $\mathrm{Di}^{\mathrm{a}}$ & $\mathrm{V}$ & VI \\
\hline 0 & 0 & 0 & 0 & 0 & 0 \\
\hline \multicolumn{6}{|c|}{ ENZ : 酵素法（パパイン処理赤血球試薬を用いた酔素 2 段法） } \\
\hline \multicolumn{6}{|c|}{ ID-DiaCell I-II-III (lot : 45188201) } \\
\hline \multicolumn{6}{|c|}{ ID-DiaCell $\mathrm{Di}^{\mathrm{a}}$ (lot : 05984221) } \\
\hline \multicolumn{6}{|c|}{ ID-DiaScreen V VIp (lot : 45210701) } \\
\hline
\end{tabular}

2 件において異常反応は認めなかった。

翌朝，業務開始前のコントロール測定及び患者検体 3 件の検査に抢いて, SC の IAT で, I 赤血球試薬に弱 陽性反応を認めた（図 1) ため, 同 LOTの新しい赤血 球試薬で再検査したところ全て陰性となった. IH-1000 に搭載していた赤血球試薬を用いて用手法で SC 再検査 すると,初回測定と同じくI赤血球試薬にて陽性反応を 認めた．追加で赤血球試薬の DAT を行った結果， I ・ II・III 赤血球試薬で凝集を認めたことにより，ダラッ ムマブ感作による偽陽性を疑った。

\section{再現性の検討}

同一症例の day24 の検体を用い, IH-1000 に同一LOT の新しい赤血球試薬を搭載し, SC と DATを実施後, 次バッチで不規則抗体陰性の検体を用いて SC を行なっ た. 測定後の赤血球試薬は取り出した後, 適宜擋挥し ながら室温で静置し, 赤血球試薬にダラツムマブが吸 着しているか DAT を行った. 測定前と測定直後は全て の赤血球試薬で DAT 除性であったが，24 時間後では I 赤血球試薬で㠜集を認めた（表 $1 \mathrm{~A}$ )。凝集を認めた I 赤血球試薬の上清で $\mathrm{SC}$ を実施したが全て㓌性であり, 混入したダラッムマブは赤血球と結合していると考え られた（表1B）。 


\section{考察}

IH-1000 による抗 CD38 抗体薬治療中の患者検体測定 後, SCの偽陽性反応が多発した事例を経験した. 原因 として，サンプルプローブを介したキャリーオーバー により装置内の赤血球試薬にダラツムマブが感作した ためと考えられる.

ダラツムマブは従来静注製剤のみであったが，2021 年 5 月より皮下注製哓が登場した。静注製剤の投与量 は患者体重当たりで定められていた $(8 \mathrm{mg} / \mathrm{kg})$ が，皮 下注製剤は固定用量 $(1,800 \mathrm{mg})$ である ${ }^{5}$. そのため, 低体重患者では静注製剂よりもダラッムマブの血中濃 度が高くなる可能性がある。実際, ダラツムマブ単剂 治療において皮下注製剤と静注製剂を比較した臨床試 験データによると, 体重 $55 \mathrm{~kg}$ 以下の日本人コホートに おいて, 3 コース目投与前濃度の中央值は皮下注製剤で $887(360 \sim 1,543) \mu \mathrm{g} / \mathrm{ml}$ ，静注製剂で 540 (328〜 883) $\mu \mathrm{g} / \mathrm{ml}$ であった ${ }^{6)}$. 本症例においてもダラツムマブの血 中濃度が高くなることで, 患者検体中のダラツムマブ を洗浄しきれなかった可能性がある.その他の要因と して測定プロトコルによるプローブ動作なども考えら れ，今後検討予定である.

抗 CD38 抗体薬投与後の患者検体を全自動輸血検査装 置で検査する場合には, 偽陽性が発生する可能性があ り, 注意が必要である.

著者の COI 開示 : 吉原哲 : 講演料(ヤンセンファーマ株式会社)

\section{文献}

1）日本血液学会編：造血器腫瘍診療ガイドライン 2018 年版補訂版，金原出版，東京，2020.

2) Albeniz I, Demir O, Türker-Sener L, et al: Erythrocyte CD38 as a prognostic marker in cancer. Hematology, 12: 409-414, 2007.

3) Chapuy CI, Nicholson RT, Aguad MD, et al: Resolving the daratumumab interference with blood compatibility testing. Transfusion, 55: 1545-1554, 2015.

4）杉山寛貴, 原田由紀, 大塚真哉, 他 : 多発性骨髄腫治療 薬ダラッムマブ (ダラザレックス；DARA) 導入に対す る輸血部門としての対応 3 症例を経験して. 日本輸血 細胞治療学会誌, $64: 362,2018$.

5) Mateos MV, Nahi H, Legiec W, et al: Subcutaneous versus intravenous daratumumab in patients with relapsed or refractory multiple myeloma (COLUMBA): a multicentre, open-label, non-inferiority, randomised, phase 3 trial. Lancet Haematol, 7: e370—e380, 2020.

6) Iida S, Ishikawa T, Min CK, et al: Subcutaneous daratumumab in Asian patients with heavily pretreated multiple myeloma: subgroup analyses of the noninferiority, phase 3 COLUMBA study. Ann Hematol, 100: 10651077, 2021 
FALSE-POSITIVE RESULTS IN AN IRREGULAR ANTIBODY SCREENING TEST AFTER MEASURING SAMPLES FROM A PATIENT RECEIVING ANTI-CD38 MONOCLONAL ANTIBODY USING AN AUTOMATED PRE-TRANSFUSION TESTING SYSTEM

\author{
Shinya Otsuka ${ }^{1)}$, Junko Ikemoto ${ }^{1)}$, Kyoko Yoshihara ${ }^{122}$, Mao Tsujimoto ${ }^{1)}$, Fuka Yamaguchi ${ }^{11}$, \\ Yuki Harada ${ }^{1)}$, Hiroki Sugiyama ${ }^{1)}$, Hitomi Onomoto ${ }^{1)}$, Rie Murata ${ }^{1)}$, Noriko Okuda ${ }^{1)}$, \\ Kenichi Yamahara $^{13)}$, Satoshi Higasa ${ }^{122)}$ and Satoshi Yoshihara ${ }^{12)}$ \\ ${ }^{1)}$ Department of Transfusion Medicine and Cellular Therapy, Hyogo College of Medicine Hospital \\ ${ }^{2)}$ Department of Hematology, Hyogo College of Medicine Hospital \\ ${ }^{3)}$ Laboratory of Molecular and Cellular Medicine, Institute for Advanced Medical Sciences, Hyogo College of Medicine
}

\begin{abstract}
:
Irregular erythrocyte antibody screening tests in patients treated with CD38 monoclonal antibodies lead to falsepositive results because of the surface expression of CD38 on red-blood-cell reagents. We obtained false-positive results for blood samples from multiple patients using the automated pre-transfusion testing system IH-1000 (BIO-RAD) after testing a blood sample taken from a patient treated with daratumumab. This may have been caused by residual daratumumab-bound erythrocytes from the treated patient in the device. Such an occurrence may be more or less likely depending on conditions such as drug concentration and measurement sequence. Further verification is needed. Thus, caution is warranted when testing blood samples from patients on anti-CD38 antibody therapy using an automated pre-transfusion testing system.
\end{abstract}

\title{
Keywords:
}

multiple myeloma, anti CD38 monoclonal antibody, automated pre-transfusion testing system, false positive, carryover

(C)2021 The Japan Society of Transfusion Medicine and Cell Therapy Journal Web Site: http://yuketsu.jstmct.or.jp/ 